JAHE Volume 1 Nomor 1 Tahun 2021 Halaman 6-8 Journal of Human and Education

\title{
Penyuluhan Kesehatan Reproduksi pada Remaja SMPN 3 Petang Bali
}

\author{
Yuliana \\ Fakultas Kedokteran, Universitas Udayana, Indonesia \\ Email: yuliana@unud.ac.id
}

\begin{abstract}
Abstrak
Kesehatan reproduksi adalah masalah penting yang harus diketahui sejak masih remaja. Pengetahuan remaja mengenai kesehatan reproduksi masih sangat minim. Banyak kehamilan di luar nikah sehingga remaja yang putus sekolah makin bertambah. Oleh karena itu, pada kesempatan ini diadakan penyuluhan kesehatan reproduksi pada siswa-siswi SMPN 3 Petang Bali. Tujuan kegiatan ini adalah untuk meningkatkan pengetahuan remaja mengenai kesehatan reproduksinya sehingga mereka bisa merawat kesehatan reproduksinya dengan baik. Kegiatan ini diikuti oleh 216 siswa-siswi. Kegiatan penyuluhan ini mendapatkan sambutan yang baik dari guru dan siswa. Pada akhir penyuluhan dilakukan pengucapan janji remaja secara bersama-sama oleh semua siswa. Harapan di masa mendatang adalah tim guru dan siswa secara bersama-sama terus melanjutkan penyuluhan kesehatan reproduksi secara rutin. Siswa-siswi memiliki cita-cita yang baik dan selalu teguh memegang janji remaja mereka.
\end{abstract}

Kata Kunci: kesehatan reproduksi; penyuluhan; remaja.

\begin{abstract}
Reproductive health is a crucial problem that must be known since adolescent. Adolescent knowledge about the reproductive health is very minimal. There are many pregnancies before marriages and the adolescents who didn't continue the study were increasing. Therefore, in this occasion, the health reproductive educational information training was given to the students of the Junior High School SMPN 3 Petang Bali. The purpose of this activity is to increase students' knowledge about the reproductive health so they can take care of their reproductive health well. This activity was attended by 216 students. It had been well appreciated by the teachers and students. In the last session, the adolescent promise was stated together by all students. Hopefully, in the future, teams of the teachers and students will continuously implement educational information training about health reproductive system routinely. All students have good vision and always keep their adolescent promise. Keywords: reproductive health; educational information training; adolescent.
\end{abstract}

\section{PENDAHULUAN}

Kesehatan reproduksi remaja adalah suatu hal penting yang wajib diketahui oleh semua remaja. Umumnya, remaja hanya mengetahui sebagian hal mengenai kesehatan remaja. Itupun hanya didapatkan dari teman-teman sepergaulannya. Kadang-kadang, informasi yang didapatkan bisa salah dan menyimpang jauh dari kebenaran. Pada remaja sangat rentan terjadi kehamilan di luar nikah yang berakibat pada putusnya sekolah karena masih tingginya gejolak emosional mereka dalam menghadapi masalah percintaan (Yusfarani, 2020).

Masa remaja merupakan masa dengan rentang usia berkisar 10 sampai 24 tahun. Masa ini adalah fase peralihan dari masa kanak-kanak (dependent) menuju masa dewasa (independent) dan normal terjadi pada kehidupan manusia. Dalam periode tersebut seorang remaja akan banyak sekali mengalami perkembangan dan pertumbuhan guna mencari identitas dan jati dirinya. Berbagai perubahan akan muncul baik dari sisi psikologis, fisik (pubertas) dan sosial lingkungan (Muliani et al., 2017).

Problematika kaum remaja dapat terjadi sehubungan dengan adanya perbedaan kebutuhan dan aktualisasi dari kemampuan penyesuaian diri remaja terhadap lingkungan tempat hidupnya. Masa ini amat kritis bagi remaja, karena waktu ini muncul keinginan lepas mandiri dari ketergantungan orang tua, rasa ingin tahu yang berlebihan dan mulai rentan terhadap perilaku beresiko (Ayu et al., 2020).

Berdasarkan hasil Survei Demografi Kesehatan Indonesia pada remaja tahun 2018, ternyata remaja putri yang mengetahui tentang masa subur hanya $33 \%$. Remaja pria yang paham mengenai masa subur hanya $37 \%$. Sebanyak lebih dari $80 \%$ remaja telah berpacaran (Ayu et al., 2020).

Diperkirakan $20-30 \%$ dari total populasi di masing-masing kabupaten maupun kotamadya di Indonesia adalah tergolong kaum remaja yang persentase terdistribusi secara hampir merata. Jika diestimasi dari jumlah penduduk Indonesia yang saat 
ini sekitar 250 juta, maka diperkirakan terdapat total 50-75 juta jiwa kaum remaja. Untuk di Bali, terdapat sekitar 700.000-850.000 orang yang berusia remaja hidup dari keseluruhan sejumlah 3,5 juta jiwa penduduk di Bali. Apabila kita meninjau lebih jauh lagi, maka terdapat sekitar 1 milyar penduduk dunia adalah kaum remaja (hampir 1 dari 6 penduduk) dan $85 \%$ remaja ternyata hidup di negara berkembang. Dengan keadaan piramida penduduk yang terbalik, hendaknya remaja mendapatkan prioritas perhatian dari semua pihak yang bersangkutan (Muliani et al., 2017).

Ditemukan fakta ternyata banyak remaja yang sudah aktif secara seksual, meskipun tidak selalu atas kehendak sendiri, dan di beberapa negara berkembang kira-kira separuh dari mereka sudah menikah. Aktifitas seksual dini yang tidak bertanggung jawab menempatkan remaja menghadapi berbagai tantangan resiko kesehatan reproduksi (Pahlevi et al., 2020).

Masalah kesehatan reproduksi remaja di Indonesia khusus di Bali masih kurang mendapat perhatian yang cukup sehingga banyak kalangan yang berpendapat bahwa masalah kesehatan reproduksi hanya menjadi urusan kalangan medis, padahal pemahaman terhadap kesehatan reproduksi (apalagi kesehatan reproduksi remaja) di kalangan medis sendiri juga masih minimal (Muliani et al., 2017).

Masalah kesehatan reproduksi dianggap hanyalah masalah kesehatan sebatas sekitar proses kehamilan dan melahirkan, sehingga dianggap bukan masalah kaum remaja. Membicarakan masalah kesehatan reproduksi remaja dianggap masalah tabu, karena berkaitan hubungan seks dan pendidikan seks, padahal masalah ini sangat penting untuk diketahui dan berkaitan dengan masa depan remaja di masa yang akan datang (Ansari et al., 2020).

Kegiatan pengabdian kepada masyarakat ini yang berupa penyuluhan Kesehatan Reproduksi pada Remaja bertujuan untuk membantu para remaja khususnya remaja di Bali yang memerlukan pandangan yang lebih luas tentang kesehatan reproduksi sehingga mampu untuk menjaga diri agar terhindar dari problema-problema pada remaja. Kegiatan ini juga diharapkan supaya remaja dapat tumbuh dan berkembang menjadi remaja yang bertanggung jawab dalam berperilaku sosial maupun terhadap perilaku seksual yang telah dilakukannya.

\section{METODE}

Sebelum pelaksanaan kegiatan, dilakukan terlebih dahulu penjajagan lokasi seminggu sebelum kegiatan berlangsung. Dalam penjajagan lokasi ini dimusyawarahkan mengenai waktu pelaksanaan kegiatan dengan memperhatikan masukan dari kegiatan sekolah. Kegiatan pengabdian masyarakat ini dilaksanakan pada hari Senin tanggal 10 Desember 2012 di SMPN 3 Petang Bali. Kegiatan dimulai pada pukul 09.30 WITA. Lama penyuluhan dari awal sampai akhir berlangsung 2 jam.

\section{HASIL DAN PEMBAHASAN}

Penyuluhan Kesehatan Reproduksi ini diberikan untuk siswa SMP, masing-masing diwakili oleh wakil dari kelas 1, 2 dan kelas 3. Jumlah keseluruhan adalah sebanyak 216 siswa. Sekitar 25 pertanyaan diajukan oleh siswa-siswa. Topik ini sangat menarik dan penting diketahui oleh pada siswa. Tampak siswa sangat tertarik dan antusias mengikuti ceramah pada gambar 1 .

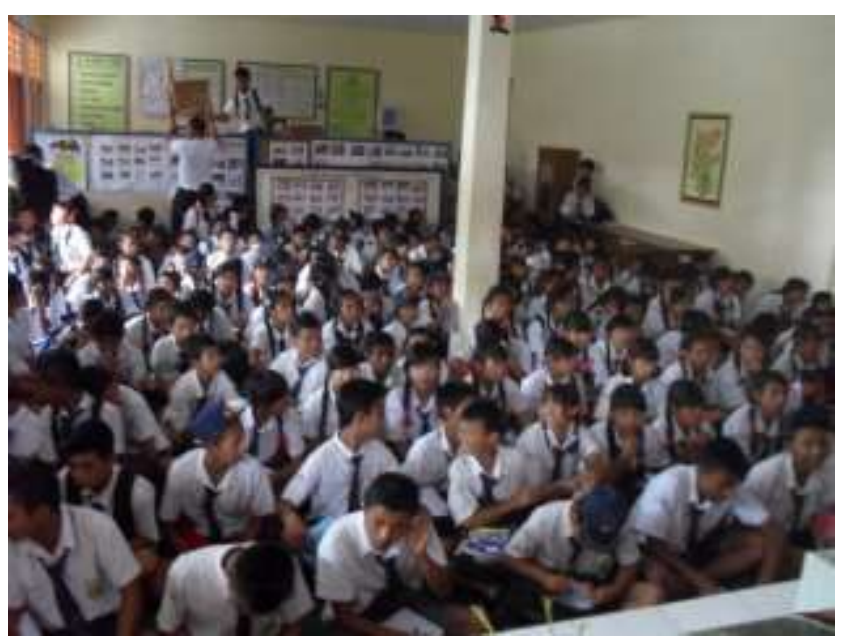

Gambar 1. Tampak siswa-siswi antusias mendengarkan ceramah penyuluhan kesehatan reproduksi

Pada saat penyuluhan, digunakan power point, LCD, dan mikrofon. Penyuluhan dilakukan di ruangan aula sekolah SMPN 3 Petang. Materi yang diberikan adalah tentang anatomi reproduksi perempuan dan laki-laki secara normal, perkembangan ciri-ciri seksual pada perempuan dan laki-laki, penyakit kelamin seksual, keluarga berencana, proses kehamilan, dan persalinan. Pada awal penyuluhan, siswa-siswi terlihat malu-malu untuk bertanya, namun pada saat terakhir, sangat banyak yang mengajukan pertanyaan. Mereka berperan aktif, mau menjawab, dan mengajukan pertanyaan kepada narasumber.

Janji Remaja yang diucapkan pada akhir penyuluhan isinya adalah remaja ini harus mampu menjaga kehormatan dirinya dari awal sampai akhir. Mereka tidak akan dengan mudah menyerahkan segalanya pada cinta masa muda. Sebaliknya, remaja tetap akan memegang teguh cita-citanya dan berjuang sampai akhir. Semua siswa mengucapkan janji remaja dengan khidmat seperti yang tampak pada gambar 2 . 


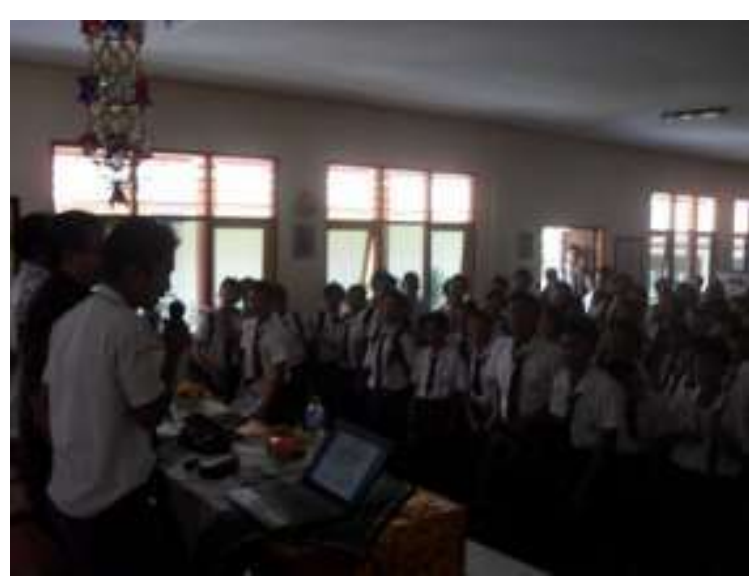

Gambar 2. Tampak siswa-siswa bersama-sama mengucapkan Janji Remaja di akhir sesi penyuluhan

Pengetahuan siswa tentang kesehatan reproduksi meningkat pada akhir dari penyuluhan ini. Sebelum diberikan penyuluhan, pengetahuan siswa tentang alat dan kesehatan reproduksi masih kurang. Melalui diskusi dan beberapa pertanyaan, akhirnya para siswa menjadi lebih paham mengenai kesehatan reproduksi.

Beberapa faktor penghambat yang dialami dalam kegiatan ini adalah waktu pelaksanaan yang bertepatan dengan jam sekolah walaupun kita telah memilih pelaksanaan tersebut pada hari Senin. Seluruh kegiatan penyuluhan ini, berjalan dengan baik dan lancar sesuai dengan yang direncanakan.

\section{SIMPULAN}

Dari pengamatan sejak dimulai sampai berakhirnya penyuluhan ini, tampak para siswa sangat tertarik dengan topik yang diberikan. Mereka sangat kritis dan mengajukan banyak pertanyaan. Wakil Kepala sekolah dan guru-guru menyambut baik kedatangan kita, karena diharapkan ada peningkatan pengetahuan mengenai kesehatan reproduksi anak didiknya. Harapan mereka anak didiknya tidak ada yang mengalami kegagalan dalam bergaul dengan lawan jenisnya, mengingat usia mereka memasuki usia pubertas.

Beberapa saran yang dapat dikemukakan yang berhubungan dengan kegiatan penyuluhan ini adalah kegiatan seperti ini hendaknya dilakukan secara berkesinambungan dan dapat diberikan oleh guru di sekolah. Sebaiknya kegiatan semacam ini diberikan mulai dari siswa kelas satu.

\section{DAFTAR PUSTAKA}

Ansari, R., Suwarni, L., Selviana, Rochmawati, \& Mawardi. (2020). Media Komik Sebagai Alternatif Media Promosi Kesehatan Seksualitas Remaja. Jurnal Ilmiah Kesehatan, 19(1), 10-14. Ayu, M. I., Situngkir, D., Nitami, M., \& Nadiyah. (2020). Program Peningkatan Pengetahuan Kesehatan Reproduksi Remaja Di SMK "X" Tangerang Raya. Jurnal Kreativitas Pengabdian Kepada Masyarakat, 3(April), 87-95.

Muliani, Widianti, I. G. A., Wardana, N. G., Yuliana, \& Karmaya, M. (2017). Tahap pertumbuhan dan perkembangan tanda-tanda seks sekunder remaja SMN 4 Bangli, Desa Pengotan, Kecamatan Bangli. Medicina, 48(2), 19-33.

Pahlevi, I., Nasution, A., Sari, B., \& Gajah, I. (2020). Tingkat Pengetahuan, Sikap, dan Perilaku Remaja tentang Kesehatan Reproduksi di SMK Negeri 8 Medan. Scripta Score Scientific Medical Journal, 2(1), 38-43.

Yusfarani, D. (2020). Pengetahuan dan Sikap Mahasiswi Program Studi Pendidikan Islam Anak Usia Dini (PIAUD) Tentang Kesehatan Reproduksi. Jurnal Aisyiyah Medika, 5(1), 2135 . 